\title{
ENTREVISTA COM IRACEMA GA RÃ NASCIMENTO
}

\author{
CLÉMENTINE MARÉCHAL ${ }^{1}$ \\ UFRGS
}

Iracema Nascimento é uma kujá (xamã) kaingang, sonhadora, parteira e conhecedora das ervas, folhas e raízes do mato. Ela é também uma importante liderança política kaingang que fortalece, com os conhecimentos dos seus antepassados, uma difícil e incansável luta pela terra no sul do Brasil. Professora pelo programa dos saberes indígenas Abya Yala, ela se dedica também a ensinar para os fóg ("brancos") seus saberes, com a esperança de encontrar nesses jovens fiéis aliados para continuar lutando para proteger a natureza da sua destruição pelos avanços do capital e do Estado colonial.

\footnotetext{
${ }^{1}$ Graduada em Etnologia (Université Paris-Ouest Nanterre). Mestre em Antropologia Social pela UFRGS e doutoranda em Antropologia Social pela UFRGS. Pesquisadora associada ao Núcleo de Antropologia das Sociedades Indígenas e Tradicionais (NIT/UFRGS). Autora do livro "Sonhar, Curar, Lutar: Colonialidade, Xamanismo e Cosmopolítica Kaingang no Rio Grande do Sul". Prismas, 2018. E-mail: clementine.marechal08@gmail.com.
} 
Clémentine Maréchal - Entrevista com Iracema Ga Rã Nascimento

Imagem 1 - Iracema Nascimento no morro Santana.

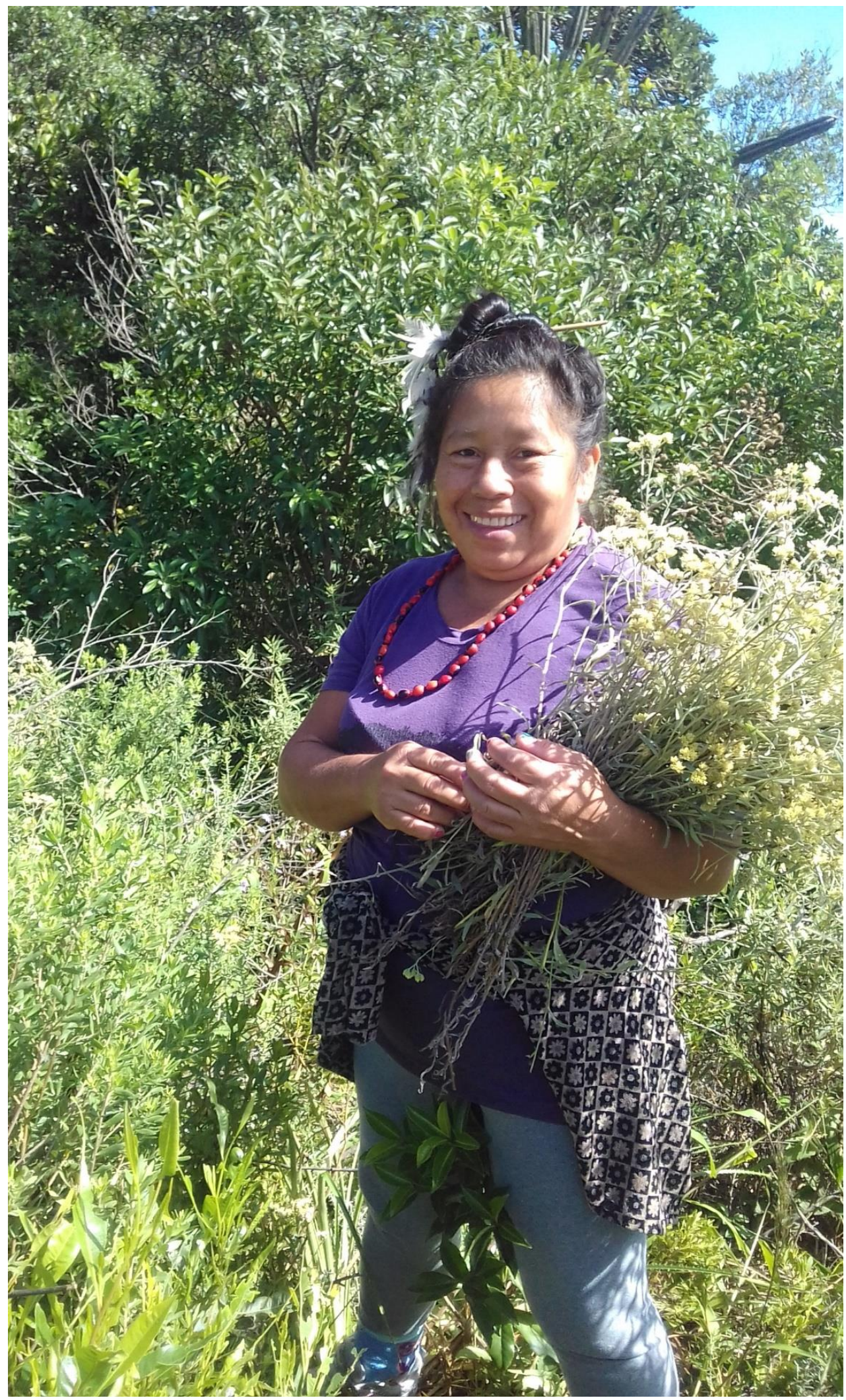

Fonte: Fotografia de Clémentine Maréchal, março de 2017. 
Clémentine: Iracema você é uma liderança política kaingang importante e você também atua hoje na UFRGS como professora do programa dos Saberes Indígenas. Qual é, para você, a importância de ensinar para os fóg ("brancos") na universidade?

Iracema: Essa é minha opinião, mas é muito importante para os fóg, que estão na universidade e que não conhecem a realidade indígena, conhecer a realidade indígena. Como sou Kaingang, posso passar a realidade, é muito importante, não tanto para mim como para meus filhos e netos. Claro que é importante para os brancos conhecerem a cultura, a língua e o respeito que nós temos pela natureza. Esse respeito pela natureza é uma formação para o futuro para o nosso país. $\mathrm{Na}$ academia poderiam ter pensado nisso antes, a convivência com a natureza. Pois é, a gente quer sempre estar livre, não fechados em sala de aula. Como liderança, eu penso isso. Aqui é uma passagem e convivemos juntos e nos entendemos. Assim também deveria ser na universidade.

Clémentine: Falando da universidade, como você vê a inserção dos Kaingang dentro da universidade? Quais são os aportes da universidade para a luta kaingang e quais são seus limites?

Iracema: Para os Kaingang a universidade é importante para buscar carreiras como o direito. É importante também para os jovens se formarem. Antes, a gente não tinha possibilidade de nos formar e hoje eles têm esse direito e podem buscar entender o outro lado, quer dizer, o lado dos fóg. Também eles podem entender bem as tecnologias e assim poder dar um uso melhor para elas, que possam beneficiar a todos, tanto aos estudantes quanto à natureza. Nós, indígenas, estamos hoje nas duas culturas, então é importante que nossos jovens tenham acesso à universidade; eles precisam dos diplomas hoje para encontrar trabalho. 
Por exemplo, com uma formação em letras, um jovem pode ser professor, com uma formação em medicina, ele pode ser médico, dentista por exemplo. Assim, eles podem atuar nas nossas aldeias e nós depender menos dos fóg também.

Mas também, a universidade ela, ela tem suas leis internas e eu acho que poderia se abrir mais para os estudantes indígenas, para sua cultura, para eles poderem fazer suas rezas e para aprender com o conhecimento das suas mães, com os saberes dos seus avos e dos seus antepassados. Isso, a universidade está custando a entender e isso dificulta nosso caminho. Sei que existe uma lei interna mas cada povo tem sua própria formação e os jovens indígenas têm direito a caminhar juntos com os outros, mas respeitando seus próprios conhecimentos; a universidade parece que não está aberta para isso. Parece que eles não querem nos entender, não sei se é porque ainda tem muita discriminação dentro da universidade, mas é assim: nossos filhos buscam estudar na cultura dos fóg mas são poucos os fóg que querem se abrir a nossa linha. Os Kaingang, eles trabalham com a comunidade. Por exemplo, agora estamos lutando para a casa de estudante que já poderia estar construída, os jovens precisam de um lugar para morar, especifica para eles, para os indígenas porque ali eles podem fazer sua reza, suas danças e convidar também os outros colegas que não são indígenas, se eles se interessam em aprender. Nós sempre estamos dispostos a aprender juntos, mas naquelas "casas" entre quatro paredes, não tem como, não, não tem como. Agora, na universidade, os indígenas falam na sua língua e os demais acham que estão falando mal deles, mas não é isso. E o reitor que é cacique da universidade, ele tem que entender isso.

Clémentine: Você, Iracema, também é conhecida por ser uma poderosa kujá (xamã), poderia comentar um pouco para nós sobre seu trabalho?

Iracema: O kujá é um sonhador. Mas para sonhar, eu tenho que tomar minhas ervas, meu chá; depois disso eu sei e eu busco o que tem que 
fazer. Esse é um trabalho que pratico já desde criança, é um dom que a natureza me deu e que logo meus avós souberam me explicar. Por exemplo, quando acontece algo, eu sonho antes, sem saber. Às vezes não sei quem são as pessoas, mas sei que algo vai acontecer com elas. Então tenho que tomar outro chá, e daí eu sei bem como fazer para ajudar a pessoa. Pode ser através dos sonhos que eu consigo curar a pessoa, mas às vezes eu tenho que me encontrar com ela pessoalmente.

Como eu sou parteira, eu ajudo as mamães grávidas, são elas que me procuram, eu dou meu remédio com ervas para elas, para o nenê nascer forte. Faço massagem para o parto acontecer sem dor; esse é meu trabalho, e eu faço ele sempre com muito amor e carinho. Quando eu morava na aldeia, já ajudei muitas mulheres a ganharem seus filhos, nem lembro o número. Mas já na cidade, aqui em Porto Alegre, já ajudei oito mamães. A última está por ganhar seu filho. Eu trato as crianças para elas ficarem bem fortes, eu mando as mães delas tomarem remédios de ervas. Às vezes me sinto tão triste porque há tantas coisas com as quais eu não consigo fazer nada, mas eu vou tentando conforme a natureza me alcança e conforme as noites que eu entendo. Hoje em dia meu trabalho é mais difícil ainda, porque o mato está desaparecendo e tudo está contaminado. Para muitos fóg, vai ser difícil entender o que é kujá, mas eu sei que devo fazer isso, está dentro de mim, e meus avós e meus pais me ensinaram como fazer.

Clémentine: Como você acha que os saberes dos kujá podem ajudar à luta kaingang e o futuro dos povos indígenas?

Iracema: Eu sempre tenho esperança, e sabe por quê? Porque eu penso que nós Kaingang, agora que estamos nos misturando, tentamos tocar no coração de outros povos para que sejam parceiros. Eu estou mostrando o caminho que temos que seguir. Sempre faço meu trabalho com amor, com o coração. Eu busco tocar no coração dos outros povos para que se tornem parceiros dos meus futuros Kaingang. Hoje não luto 
só pelos meus Kaingang, eu luto pela vida, pelos povos, pelos bichinhos que estão vivos. Busco que todos os povos saibam entender, que saibam multiplicar esse conhecimento. Essa é minha esperança. Sei que não vai ser fácil, mas estou tentando mostrar o caminho para os fóg. Nós Kaingang preferimos morrer pela mãe terra. Esse é o único caminho que encontrei, ensinar para os outros povos, tanto na faculdade como nos meus sonhos. E espero que os professores que estão na universidade saibam ensinar com amor e com o coração, e que eles saibam pensar e lembrar da sua raiz. Porque todos nós que estamos aqui e que nascemos nesse lindo mba mág (Brasil) temos que sentir e pensar, temos que botar as mãos no coração e lembrar que todos nós somos um pedaço desse chão.

Clémentine: Qual é sua avaliação das políticas oficiais indigenistas, antigas e atuais?

Iracema: Se eu te dizer que dou nota 10 para eles, estou mentindo. E sinto dizer isso, porque eles já são mandados, são os empregados. Eu sei que daria para fazerem direito as coisas, se realmente quisessem, mas que não fazem. Daria para se envolverem com as comunidades, conviverem e conhecerem melhor os problemas delas, mas não fazem, porque são mandados. Eles são mandados pelo sistema para destruir a natureza. Eles fazem isso porque são obrigados e, como kujá, eu não posso condenar eles; eles são uma vida mas eles fazem isso porque eles têm que fazer o que seus mandantes dizem, eles trabalham pelos destruidores da natureza, pelos seus próprios destruidores. Por isso eles fazem o que eles fazem: eles fazem e não sabem o que estão fazendo, eles fazem porque tem mais coisas atrás deles mandando fazer. E o que eles fazem também tenta meu povo. Minhas lideranças ficam doentes por causa disso. Nós, como kujá, vamos continuar lutando por essas vidas. 
Esse é nosso trabalho, esse é trabalho do meu jamréz, que convive com mato, com folhas, com Taikuantón ${ }^{3}$.

Clémentine: Sabemos que no sul do país a luta pela terra é bastante difícil. Já aconteceram vários conflitos e perseguições de lideranças kaingang. Que recomendações você faria para os jovens kaingang e seus aliados para reconquistar a terra?

Iracema: Os jovens têm que continuar resistindo, resistindo com seus aliados. Resistir: essa é a meta do nosso jovem. Não se corromper. Não, não vale a pena se desviar do caminho. O caminho é estreito, mas segurando a mão do outro, da companheira, do companheiro, se consegue. Nossos jovens hoje têm que estar mais firmes, têm que pisar firme; esse é o único jeito da mãe natureza ajudar. Eles têm que caminhar com o coração, com a alma pura, principalmente. Enquanto eu estiver ainda viva, conversando e resistindo, é essa minha palavra, meus conselhos para os nossos jovens.

Clémentine: E Iracema, para os antropólogos, que conselho você daria?

Iracema: Tudo mundo erra, ninguém é perfeito, mas o antropólogo tem que escrever o que a comunidade pede. Sei que o antropólogo não é quem pode decidir, mas pelo menos escrever alguma coisa que a comunidade pede. Essa é a responsabilidade dele. Também sei que tem antropólogos que têm medo de esclarecer seu trabalho; também têm uns que são mesmo contra os povos indígenas.

\footnotetext{
${ }^{2}$ Todos os seres kaingang pertencem a uma metade cosmológica: a metade Kamé, associada ao sol, à marca comprida; ou à metade Kanheru Kré, associada à lua e à marca redonda. As pessoas da mesma metade são chamadas de regré e não podem casar entre si já que são consideradas irmãs; já as pessoas de metades diferentes são chamadas de jamré e devem casar entre si. A relação entre jamré é muito importante na socialidade kaingang, pois ressalta a complementaridade na diferença.

${ }^{3}$ Outro nome para dizer Tupé, Deus.
} 
Outra coisa, os antropólogos têm que levar junto as pessoas com quem eles trabalham, eles têm que botar eles junto no trabalho, porque o trabalho que eles fazem é uma colaboração. Eles têm que nos levar a sério; meu pai, meu avô, também eles queriam ser levados a sério mas ninguém fez isso. Nós sempre fomos negados. Eu não sei se realmente foi negação ou se foi medo, mas o que eu peço hoje ao antropólogo é: escreva, mas tente mostrar a pessoa que está fazendo essa busca contigo. Conviva com o povo kaingang, conviva com o povo guarani, com os "indígenas", já que que botaram esse apelido sobre nós.

Espero que os antropólogos entendam e que sejam parceiros das pessoas de quem eles vão escrever a história. E que não escrevam nossa história para depois nos deixar de lado. Isso está errado. Eu peço que o antropólogo não faça como os políticos fazem. Quando o político quer se eleger ele vai ao povo, bate nas costas da gente, e quando se elege, ele esquece do povo. Não quero que o antropólogo faça isso. Não copiem a maldade dos políticos. 